\title{
Comment on "The importance of physical exercise during the coronavirus (COVID-19) pandemic"
}

\author{
Dedson Silva-Filho ${ }^{1}$ \\ (iD) Jairo Xavier ${ }^{2}$ \\ (iD) Leandro Cezarino ${ }^{3}$ \\ Histênio Sales ${ }^{4}$ \\ Jéssica Albuquerque
}

1. Fisioterapeuta e Professor de Educação Física, Universidade Federal da Paraíba, João Pessoa, PB, Brasil. 2. Fisioterapeuta, Centro Universitário Estácio de Sá, Recife, PE, Brasil. 3. Fisioterapeuta, Universidade Federal do Rio Grande do Norte, Santa Cruz, RN, Brasil.

4. Doutor, Hospital Regional José Fernandes Salsa, Limoeiro, PE, Brasil. 5. Psicóloga, Universidade federal da Paraíba, João Pessoa, PB, Brasil.

http://dx.doi.org/10.1590/1806-9282.66.9.1311

\section{SUMMARY}

Currently, many people have been infected by the Coronavirus disease (COVID-19) and presented cardiorespiratory symptoms caused mainly by the host immune system response and respiratory tract inflammation. So far, there is no effective treatment to fight off COVID-19 and, despite many daily speculations about new treatments and vaccines, in this article, we discuss the effectiveness of a cheap and scientific proven technique to treat and prevent several diseases. Many studies have shown the benefits of physical exercise in individuals who have practiced it routinely. This approach is a great strategy to improve people's cardiorespiratory capacity, inflammation system, and immune response. Due to the quarantine period, the practice of physical exercise at home can also be used to fight off COVID-19 and must be inserted into people's routines.

KEYWORDS: Coronavirus Infections. Betacoronavirus. Exercise.

\section{INTRODUCTION}

Coronavirus disease (COVID-19) has been spreading significantly worldwide. However, currently, several countries have presented a decrease in deaths and infections. ${ }^{1}$ Although mortality and contamination curves have been reducing, there are still many symptomatic people presenting arthralgia, myalgia, pain, headache, cough, hypotension, and cardiological malfunction. ${ }^{2,3}$

To fight off infection and symptoms generated by COVID-19 many clinical trials have been developed to test drugs ${ }^{4}$, such as hydroxychloroquine, ${ }^{5}$ lopinavir-ritonavir, ${ }^{6}$ and corticosteroid, ${ }^{7}$ but no differences were found beyond standard care regarding mortality and time of symptomatology. Nevertheless, a recent study showed that remdesivir shortens the recovery time of adults infected by COVID-19 ${ }^{8}$. It is important to mention that some side effects have been reported on people infected by COVID-19, mainly on cardiovascular function, leading to congestive heart failure, acute heart failure, syncope, ${ }^{9}$ and anemia. ${ }^{8}$ The biggest multicentric study about COVID-19 published presented that hydroxychloroquine or chloroquine used alone or associated with macrolide decreased survival and increased arrhythmias ${ }^{10}$. 
The main mechanism involved in COVID-19 pathogenesis is respiratory tract inflammation and host immunity system response. ${ }^{11}$ Patients infected by COVID-19 commonly have lymphopenia, neutrophilia, thrombocytopenia, high systemic immune inflammation, and increased protein $\mathrm{C}$ and interleukin 6 levels. The initial condition of the patient and their immune response seem to be important factors that can harm organs' functioning. ${ }^{12}$ Thus, as COVID-19 immunological and physiological processes have been elucidated, preventive strategies must be discussed to decrease the duration of symptoms and mortality in infected people.

Physical exercise emerges as a strategy to improve cardiorespiratory variables and endurance in people infected by COVID-19, ${ }^{13}$ and in those who are not infected. ${ }^{14}$ It is emphasized that individuals engaged in physical exercise programs have an increase of their cardiorespiratory levels, which is considered an important variable to protect against the emergence of several clinical conditions/diseases, such as hypertension, diabetes, and serious heart conditions. ${ }^{14}$ People with these characteristics are at higher risk of severe COVID-19 illness. ${ }^{15}$

Besides, older people, which are part of the risk group, present an increase of inflammatory cells, such as cytokines and interleukins $6 .{ }^{16}$ It has been shown that physical exercise may modulate the response of several inflammatory mediators. ${ }^{17-21}$ Adaptations in exercise parameters play an important role in generating benefits on immunity and inflammation systems. ${ }^{22}$ It is also highlighted that aerobic training has been used to prevent and reduce the risk of several conditions, such as endothelial dysfunction, obesity, diabetes, and high blood pressure. ${ }^{23}$ As a result, we believe that this protective nonpharmacological approach can be an important strategy for decreasing symptoms and deaths caused by COVID-19.
Telehealth exercise protocols have been developed to help people who present different conditions. ${ }^{24,25}$ Besides, the use of video games to insert people in an immersive environment and stimulate them to practice exercise to improve quality of life has been used in older adults ${ }^{26}$, children ${ }^{27}$ and individuals with different physical limitations. ${ }^{28}$ These approaches could also be applied during the COVID-19 pandemic period because people worldwide must be in quarantine to avoid virus spreading ${ }^{29,30}$. The social isolation period has been traumatic in different ways, ${ }^{31}$ stress, ${ }^{32}$ anxiety, and depression ${ }^{33}$ have been experienced by several people. Exercise can be excellent to improve these symptoms ${ }^{34}$ and should be stimulated to be performed at home during this tough time. Considerations about the opening of gyms and public spaces for the practice of exercise must be done with caution because there can be an increase in infections.

Although there is no vaccine to fight off COVID19 , thinking in the long term, since physical exercise has also been related to improving the effects of the vaccine,${ }^{35}$ it would be important to start preparing for this time, improving antibody response by exercising. Physical exercise must be considered a preventive strategy to fight off COVID-19.

\section{CONCLUSION}

Many people have been suffering because of the routine changes caused by the quarantine, deaths reported on TV, speculations about new treatments, risk of losing their jobs, and no prediction about the end of the pandemic. Physical exercise is a cheap and easy strategy that should be encouraged during the COVID-19 pandemic because it has been worthy to treat and prevent many cardiorespiratory and physical manifestations developed by people.

\section{RESUMO}

Atualmente, muitas pessoas ainda têm sido infectadas pelo Coronavírus (COVID-19) e apresentado sintomas cardiorrespiratórios gerados principalmente pela resposta do sistema imune do hospedeiro e inflamação do trato respiratório. Até agora, não existe nenhum tratamento efetivo para combater o COVID-19 e apesar de muitas especulações diárias sobre novos tratamentos e vacinas, neste artigo, nós discutimos sobre a efetividade de uma técnica barata e cientificamente comprovada para tratar e prevenir diversas doenças. Muitos estudos têm demonstrado os benefícios do exercício físico em indivíduos que tem praticado de forma rotineira. Esta abordagem é uma excelente estratégia para melhorar a capacidade cardiorrespiratória, sistema inflamatório e resposta imune. Devido ao período de quarentena, a prática de exercício físico em casa pode também ser usada para combater o COVID-19 e deve ser inserida na rotina das pessoas. 


\section{REFERENCES}

1. World Health Organization. Coronavirus disease (COVID-19). Situation Report - 120. Geneva: World Health Organization; 2020. [cited 2020 May 5]. Available from: https://www.who.int/docs/default-source/coronaviruse/ situation-reports/20200519-COVID-19-sitrep-120.pdf?sfvrsn=515cabfb_2

2. Lechien JR, Chiesa-Estomba CM, De Siati DR, Horoi M, Le Bom SD, Rodriguez $\mathrm{A}$, et al. Olfactory and gustatory dysfunctions as a clinical presentation of mild-to-moderate forms of the coronavirus disease (COVID-19): a multicenter European study. Eur Arch Otorhinolaryngol. 2020;277(8):2251-61.

3. Kochi AN, Tagliari AP, Forleo GB, Fassini GM, Tondo C. Cardiac and arrhythmic complications in patients with COVID-19. J Cardiovasc Electrophysiol. 2020;31(5):1003-8.

4. Rosa SGV, Santos WC. Clinical trials on drug repositioning for COVID-19 treatment. Rev Panam Salud Publica. 2020;44:e40.

5. Tang W, Cao Z, Han M, Wang Z, Chen J, Sun W, et al. Hydroxychloroquine in patients with mainly mild to moderate coronavirus disease 2019: open label, randomised controlled trial. BMJ. 2020;369:m1849.

6. Cao B, Wang Y, Wen D, Liu W, Wang J, Fan G, et al. A trial of lopinavir-ritonavir in adults hospitalized with severe COVID-19. N Engl J Med. 2020;382(19):1787-99.

7. Lee $\mathrm{N}$, Allen Chan KC, Hui DS, Ng EKO, Wu A, Chiu RWK, et al. Effects of early corticosteroid treatment on plasma SARS-associated coronavirus RNA concentrations in adult patients. J Clin Virol. 2004;31(4):304-9.

8. Beigel JH, Tomashek KM, Dodd LE, Mehta AK, Zingman BS, Kalil AC, et al. Remdesivir for the treatment of COVID-19: preliminary report. The New England Journal of Medicine. N Engl J Med. 2020;NEJMoa2007764.

9. Tönnesmann E, Kandolf R, Lewalter T. Chloroquine cardiomyopathy: a review of the literature. Immunopharmacol Immunotoxicol. 2013;35(3):434-42.

10. Mehra MR, Desai SS, Ruschitzka F, Patel AN. Retracted: Hydroxychloroquine or chloroquine with or without a macrolide for treatment of COVID-19: a multinational registry analysis. Lancet 2020;S0140-6736(20)31180-6.

11. Huang $C$, Wang $Y, L i X$, Ren L, Zhao J, Hu Y, et al. Clinical features of patients infected with 2019 novel coronavirus in Wuhan, China. Lancet. 2020;395(10223):497-506.

12. Zhang B, Zhou X, Qiu Y, Song Y, Feng F, Feng J, et al. Clinical characteristics of 82 cases of death from COVID-19. PLoS One. 2020;15(7):e0235458.

13. Liu K, Zhang W, Yang Y, Zhang J, Li Y, Chen Y. Respiratory rehabilitation in elderly patients with COVID-19: a randomized controlled study. Complement Ther Clin Pract. 2020;39:101166.

14. Al-Mallah MH, Sakr S, Al-Qunaibet A. Cardiorespiratory fitness and cardiovascular disease prevention: an update. Curr Atheroscler Rep. 2018;20(1):1.

15. Centers for Disease Control and Prevention (CDC). People with certain medical conditions. [cited 2020 May 5]. Available from: https://www.cdc.gov/ coronavirus/2019-ncov/need-extra-precautions/groups-at-higher-risk.html

16. Dobbs RJ, Charlett A, Purkiss AG, Dobbs SM, Weller C, Peterson DW. Association of circulating TNF-alpha and IL-6 with ageing and parkinsonism. Acta Neurol Scand. 1999;100(1):34-41.

17. Spielmann G, McFarlin BK, O'Connor DP, Smith PJ, Pircher H, Simpson RJ. Aerobic fitness is associated with lower proportions of senescent blood T-cells in man. Brain Behav Immun. 2011;25(8):1521-9.

18. Shinkai S, Kohno H, Kimura K, Komura T, Asai H, Inai R, et al. Physical activity and immune senescence in men. Med Sci Sports Exerc. 1995;27(11):1516-26.
19. Pedersen BK, Bruunsgaard H. Possible beneficial role of exercise in modulating low-grade inflammation in the elderly. Scand | Med Sci Sports. 2003;13(1):56-62.

20. Phillips MD, Flynn MG, McFarlin BK, Stewart LK, Timmerman KL. Resistance training at eight-repetition maximum reduces the inflammatory milieu in elderly women. Med Sci Sports Exerc. 2010;42(2):314-25.

21. Woods JA, Ceddia MA, Wolters BW, Evans JK, Lu Q, McAuley E. Effects of 6 months of moderate aerobic exercise training on immune function in the elderly. Mech Ageing Dev. 1999;109(1):1-19.

22. Simpson RJ, Kunz H, Agha N, Graff R. Exercise and the regulation of immune functions. Prog Mol Biol Transl Sci. 2015;135:355-80.

23. Nasi M, Patrizi G, Pizzi C, Landolfo M, Boriani G, Dei Cas A, et al. The role of physical activity in individuals with cardiovascular risk factors: an opinion paper from Italian Society of Cardiology-Emilia Romagna-Marche and SICSport. J Cardiovasc Med (Hagerstown). 2019;20(10):631-9.

24. Rawstorn JC, Gant N, Direito A, Beckmann C, Maddison R. Telehealth exercise-based cardiac rehabilitation: a systematic review and meta-analysis. Heart. 2016;102(15):1183-92.

25. Adamse C, Dekker-Van Weering MG, van Etten-Jamaludin FS, Stuiver MM. The effectiveness of exercise-based telemedicine on pain, physical activity and quality of life in the treatment of chronic pain: a systematic review. ) Telemed Telecare. 2018;24(8):511-26.

26. Shake MC, Crandall KJ, Mathews RP, Falls DG, Dispennette AK. Efficacy of Bingocize $^{\circledR}$ : a game-centered mobile application to improve physical and cognitive performance in older adults. Games Health J. 2018;7(4):253-61.

27. Tarakci D, Ersoz Huseyinsinoglu B, Tarakci E, Razak Ozdincler A. Effects of Nintendo $\mathrm{Wii}_{\mathrm{ii}} \mathrm{Fit}^{\circledR}$ video games on balance in children with mild cerebral palsy. Pediatr Int. 2016;58(10):1042-50

28. Mura G, Carta MG, Sancassiani F, Machado S, Prosperini L. Active exergames to improve cognitive functioning in neurological disabilities: a systematic review and meta-analysis. Eur J Phys Rehabil Med. 2018;54(3):450-62.

29. Jiménez-Pavón D, Carbonell-Baeza A, Lavie C). Physical exercise as therapy to fight against the mental and physical consequences of COVID-19 quarantine: Special focus in older people. Prog Cardiovasc Dis. 2020;63(3):386-8.

30. Wilder-Smith A, Freedman DO. Isolation, quarantine, social distancing and community containment: pivotal role for old-style public health measures in the novel coronavirus (2019-nCoV) outbreak. J Travel Med. 2020;27(2):taaa020. doi: 10.1093/jtm/taaa020.

31. Inter-Agency Standing Committee. Addressing mental health and psychosocial needs during the COVID-19 outbreak. [cited 2020 April 6]. Available from: https://www.mhinnovation.net/resources/addressing-mental-healthand-psychosocial-needs-during-COVID-19-outbreak.

32. Brooks SK, Webster RK, Smith LE, Woodland L, Wessely S, Greenberg N, et al. The psychological impact of quarantine and how to reduce it: rapid review of the evidence. Lancet. 2020;395(10227):912-20.

33. Lei L, Huang X, Zhang S, Yang J, Yang L, Xu M. Comparison of prevalence and associated factors of anxiety and depression among people affected by versus people unaffected by quarantine during the COVID-19 epidemic in Southwestern China. Med Sci Monit. 2020;26:e924609.

34. Saeed SA, Cunningham K, Bloch RM. Depression and anxiety disorders: benefits of exercise, yoga, and meditation. Am Fam Physician. 2019;99(10):620-7.

35. Kohut ML, Arntson BA, Lee W, Rozeboom K, Yoon K, Cunnick JE, et al. Moderate exercise improves antibody response to influenza immunization in older adults. Vaccine. 2004;22(17-18):2298-306. 